\title{
Establishing the circumstances to be proven during verification of tax crime reports
}

\author{
Gaisa Mosovich Meretukov ${ }^{1}$, Aleksander Aleksandrovich Tushev, and Aleksander Yuryevich \\ Korchagin \\ Kuban State Agrarian University named after I.T. Trubilin, Department of Criminalistics, Department \\ of Criminal Procedure, Krasnodar, Russia
}

\begin{abstract}
The primary purpose of this scientific work is to study the specifics of initiating criminal cases on crimes under Articles 198, 199, 199.1, 199.2, 199.3, and 199.4 of the Criminal Code of the Russian Federation following current legislation. Using methods of analysis of legislation, published scientific works on the subject, legal comparison, study of practical activities of investigation bodies, the article developed scientific provisions and practical recommendations, which can be used in criminalistics and the activities of investigation bodies. In accordance with subparagraph "a" of paragraph 1 of part 1 of Article 151 of the Criminal Code of the Russian Federation, these crimes are investigated by investigators of the Investigative Committee of the Russian Federation. The reasons for initiating a criminal case can be both reports from the inquiry and the tax authorities (Part 7-9 of Article 144 of the Criminal Code of the Russian Federation). Another result of the work considered the joint activities of these bodies to establish the event and traces of the crime during the verification of tax crime reports and the conclusions obtained during the analysis of the applied forensic methods and means during such verification. The novelty of the work lies in the definition of the circumstances included in the subject of proof, which can be established in deciding the issue of initiation of criminal proceedings for this category of crimes. It also substantiates the problems that arise during the verification of messages. The results and novelty of the study will allow optimizing the activities of the bodies of preliminary investigation and inquiry.
\end{abstract}

Keywords: Taxes, crimes, preliminary investigation bodies, preliminary inspection

\section{Introduction}

In recent years, the criminal procedure legislation on the procedure and grounds for initiating criminal cases on tax crimes has often changed in Russia. Such inconstancy of the state's legislative policy in this area caused many problems in the practical activities of law enforcement agencies to identify, initiate and investigate these crimes.

In the structure of economic crimes, a special place is occupied by crimes committed in the field of taxation. To exercise control in this area, the Federal Tax Police Service of the

\footnotetext{
${ }^{1}$ Corresponding author: crimkubgau@mail.ru
} 
Russian Federation was established based on special divisions of the Ministry of Internal Affairs and the FSB (the successor of the KGB) by Presidential Decree No. 262 of 18.03.1992. However, after 11 years, by Decree of the President of the Russian Federation No. 306 of 11.03.2003, it was abolished. Currently, the Ministry of Internal Affairs of the Russian Federation has the Main Directorate for Combating Economic Crimes and Corruption and its territorial bodies, and the FSB system has the Economic Security Service, which also deals with tax crime detection. Since 2012, the investigation of these cases has been transferred to the divisions of the Investigative Committee of the Russian Federation. In foreign countries, special bodies are also created to detect and investigate tax crimes [1].

Statistics on tax crimes in the Russian Federation show their fluctuation in the total number of crimes. For example, in 1977, 2001 such crimes were committed in the country, and by 2003 their number had grown to 16,271 crimes. By 2010, these indicators had increased by 24.9 percent [2]. In 2017, there were 5,113 cases of tax crimes under investigation [3]. In 2019, 4,503 such crimes were identified [4]. Tax crimes are already taking on an international character [5].

\section{$2 \quad$ Methods}

The methodological basis of the study is universal, general scientific, and particular scientific methods of knowledge used by the legal science in the object-subject area of knowledge of the general theory of law. In addition, a number of synthetic, integrative methods of research are used, which are included in the methodology of interdisciplinarity, which is relevant for modern socio-humanitarian science.

The methodology for the study of methods and techniques to identify and verify signs of tax crimes is the analysis of legislation, generalization, and analysis of investigative practice, the use of existing scientific developments in this area. Based on the study of practice and current legislation, the most common reasons for checking reports on tax crimes are the report of an employee of the Department of the Ministry of Internal Affairs to combat economic crimes and anti-corruption on the detection of signs of crime detected in the performance of their duties; submission to the investigator a memorandum on the results of operational and investigative activities; materials received by departments of the Investigative Committee of the Russian Federation from the territorial tax inspection of the Russian FTS. When initiating a criminal case, take into account the provisions of Article 76.1 Part 1 of the Criminal Code of the Russian Federation (CC RF) and Article 28.1 Part 1 of the CC RF that a non-payer, who has committed a crime for the first time, is exempt from criminal responsibility if he has fully paid the amount of arrears and fines in the amount determined by the RF Tax Code.

\section{$3 \quad$ Results}

The subject of proof provided for in Article 73 of the CC RF should be considered concerning all types of crimes. It is supplemented and detailed, taking into account the circumstances of the specific crime committed. Scientific proceduralists consider equal the concept of the subject of proof and the circumstances to be proved [6, 7]. Article 73 of the CC RF contains criminal procedural circumstances and criminalistic, criminal-legal, and criminological ones that require establishing and proving by criminal-procedural means. In the course of verification, it is already possible to establish some of the circumstances that are part of the subject of proof in a criminal case.

In cases of tax crimes, it is crucial to establish the method of preparation, commission, 
and concealment of traces. As correctly noted by R. S. Belkin, "if we remove from the content of Article 73 of the CC RF the data of criminal-law and procedural, as well as criminological nature, then it will have only one truly criminological element - the method of committing, the method of concealing the crime and the traces left" [8].

A trace pattern can be established when studying accounting, financial, and business transactions, accounting reports in the presence of material forgery in accounting, or tax documents when making calculations at the time of calculating taxes and (or) fees. It is also possible to track the traces in the constituent or title documents. It can also be traced in non-compliance with the rules of accounting or write-off of inventory, long-term investment in off-budget assets, the calculation of staff costs, depreciation costs on capital investments; in the field tax audit certificate, in written objections to this certificate; when appealing this certificate - in complaints and responses to them by the tax authorities.

Based on the traced picture, we can model the mechanism of a tax crime, the knowledge of which allows selecting the necessary forensic methods and means of establishing the method of preparation, the commission of the crime, and the concealment of traces. The mechanism of a tax crime is one of the foundations for forming a private forensic methodology for investigating a tax crime.

The list of circumstances to be established during the verification of a tax crime report is also closely interrelated with its model mechanism, developed based on the most informative elements of the criminalistic characteristics of the investigated category of crimes [9-13].

Characteristics of the personality of the criminal, his ability and skills to work with accounting, financial, credit, and tax documents, which allow at the professional level to carry out criminal activity by entering false data in the tax returns and statements, or in the personal interests to distort the tax and (or) fee to the budget, or to hide the objects of taxation is also important. Falsified documents regulating the formation of a false company and supporting accounting and financial documents can be concealed.

In recent years, when preparing textbooks and training manuals, scientists include the most informative elements in the structure of the criminalistic characteristic: the characteristic of the offender; typical ways of committing and typical traces of the crime, as well as the consequences of the crime, which allow identifying the fact of violation of tax legislation $[14,15]$.

We consider it possible to include the following elements in the structure of the criminalistic characteristic: the method of preparation, forming traces of criminal activity; the identity of the criminal; hidden objects (immovable property, used raw materials or finished products and money, etc.), spatial and temporal factors, as well as the causal relationship between these elements.

\section{Discussion}

The determination of the circumstances that need to be established during the preliminary verification of reports of tax crimes is directly influenced by the characteristics of the elements of the crimes under consideration. For example, Articles 198 and 199 of the CC RF set out the signs of the objective side of the crimes as evasion of taxes and (or) fees by individuals or legal entities by not submitting a tax return or other documents, or by including in the tax return or other documents knowingly false information committed on a large scale. The use of the term "other documents" should be understood as the need to establish these documents, i. e., the range of circumstances to be proved expands. These can be extracts from the book of sales, the book of income and expenses of business operations, a copy of the journal of invoices received and issued, the calculation of advance payments and payroll. 
The method of committing a crime is interrelated with the method of preparing and concealing a crime. They are not covered by legal categories, but from a forensic point of view, they are essential for establishing traces of a crime, and through them, the identity of the criminal, the accomplices and the forms of their complicity, the circumstances that contributed to the commission of the crime, etc. can be established.

Following Part 1 of Article 144 of the CC RF, when checking a report on a crime, an investigator, an inquirer, an inquiry body, or the head of an investigative body has the right to demand documents and objects, seize them, and demand documentary checks and audits. According to the report on tax crimes, the main means of obtaining evidentiary or orienting primary source information is a documentary check or audit and the request for accounting, financial, economic, and tax documents.

Sometimes there is a need to check the bank documentation on financial transactions, materials, and orders on personnel matters related to the reception, transfer, and dismissal of employees, as well as accounting, the procedure for the execution of the salary fund, the calculation of the insurance and savings. To do this, it is necessary to request the above documents from various agencies: registration and cadastral division, tax inspection, banks and credit organizations, enterprises with which the taxpayer had relations on financial and other settlements and operations. Similar documents can be obtained from Rosfinnadzor, the Accounting Chamber, the Federal Service for Financial and Budgetary Supervision, and the Federal Customs Service.

Unfortunately, the Criminal Procedure Law does not regulate the procedure and conditions for requesting documents or items and conducting documentary checks and audits. This gap in the legislation, according to many scientists, is long overdue to eliminate and regulate the production of these procedural actions.

The operational-search activity of the bodies of inquiry is of no minor importance in identifying and obtaining primary information about tax crimes [16] (Panov, 2017).

\section{Conclusion}

In the event of a report on the commission of a tax offense, the inquiry body is authorized to conduct a preliminary check of this report both with the help of operational search and procedural means (Part 1 of Article 144 of the CC RF). The CC RF does not specify whether the tax authorities are involved in the audit. However, based on the meaning of Part of Article 144 of the CC RF, the body of inquiry has the right to demand from them the necessary documents to oblige them to conduct a documentary check. After the inspection, the body of inquiry sends the materials to the investigator, who, following Part 9 of Article 144 of the CC RF, must send them to a higher tax authority within 3 days in relation to the tax authority in which the taxpayer or tax agent is registered to obtain a conclusion about a violation of tax legislation, or information about the audit conducted on this violation or the absence of information about a violation of tax legislation. No later than 30 days from the date of receipt of a report on a crime, based on the results of consideration of this conclusion, the investigator must decide whether to initiate or refuse to initiate a criminal case. However, without waiting for the conclusion of the tax authority, the investigator is authorized to initiate a criminal case if there is a reason and sufficient data indicating signs of a tax crime.

The disadvantage of such regulation of the procedure for initiating criminal proceedings for the crimes in question, in our view, is the possibility of duplication of verification actions by the body of inquiry and the investigator.

\section{References}


1. N.I. Solovyov, J. Foreign Legisl. and Compar. Jurisprud. 5, 28 (2016)

2. Meretukov G. M. Vyyavlenie i sobiranie kriminalisticheski znachimoi informatsii na stadii vozbuzhdeniya ugolovnogo dela ob uklonenii ot uplaty nalogov i (ili) sborov i sokrytii obektov nalogooblozheniya: monografiya [Identification and collection of criminalistically significant information at the stage of initiating a criminal case on tax evasion and (or) fees and concealment of taxable objects: monograph] (KubGAU, Krasnodar, 2013)

3. Bastrykin, A.I. Bastrykin, Protivodeistvie nalogovoi prestupnosti: Materialy Vserossiiskoi nauchno-prakticheskoi konferentsii [Countering tax crime: Materials of the All-Russian Scientific and Practical Conference], in A.M. Bagmet (ed.), Moscow, May 31, 2018 (Moscow Academy of the Investigative Committee of the Russian Federation, Moscow, 2018).

4. Prosecutor General's Office of the Russian Federation. Legal statistics portal Accessed on: June 26, 2021. [Online]. Available: http://crimestat.ru/

5. Effektivnoe mezhvedomstvennoe sotrudnichestvo $\mathrm{v}$ borbe $\mathrm{s}$ nalogovymi i inymi finansovymi prestupleniyami [Effective interagency cooperation against tax and other financial crimes] (2012). Accessed on: December 20, 2020. [Online]. Available: https://www.oecd.org/ctp/crime/Final_Russian_Domestic_Cooperation.pdf

6. A.A. Usachev (ed.), Ugolovnyi protsess: uchebnik dlya vuzov [Criminal procedure: textbook for universities] (Uright Publishing House, Moscow, 2020)

7. V.P. Bozhev, B.Ya. Gavrilova (eds.), Ugolovnyi protsess: uchebnik dlya vuzov [Criminal procedure: textbook for universities] (Uright Publishing House, Moscow, 2020)

8. R.S. Belkin, Kriminalistika: problemy segodnyashnego dnya. Zlobodnevnye voprosy rossiiskoi kriminalistiki [Criminalistics: problems of today. Topical issues of Russian criminalistics] (Publishing House NORMA, Moscow, 2001)

9. T.F. Dmitrieva, Osobennosti kriminalisticheskogo obespecheniya rassledovaniya biznes-prestuplenii: teoreticheskii i prikladnoi aspekty [Features of forensic support for investigating business crimes: theoretical and applied aspects], in G.F. Ruchkina (ed.), Biznes-aktivnost i ugolovnoe pravo: monografiya [Business activity and criminal law: monograph] (VSU named after P. M. Masherov, Vitebsk, 2020)

10. E.P. Ishchenko, A.A. Toporkov, Kriminalistika: Uchebnik [Criminalistics: textbook] (Law Firm "CONTRACT”, INFRA-M, Moscow, 2010)

11. V.D. Larichev, Law and Soc. 5(42) (2012)

12. V.V. Pushkarev, The Age of Sci., 9 (2017). https://doi.org/10.1555/2409-3203-2017-0-9-87-99

13. A.M. Khlus, Kriminalisticheskaya kharakteristika i materialnaya struktura prestupleniya $\mathrm{v}$ chastnoi metodike rassledovaniya [Criminological characteristics and material structure of the crime in a private investigation technique] (BSU, Minsk, 2019)

14. V.D. Zelensky, G.M. Meretukova (eds.), Kriminalistika: uchebnik [Criminalistics: textbook] (Publishing House "Law Center", Saint Petersburg, 2015)

15. G.M. Meretukov, Kriminalisticheskaya metodika rassledovaniya otdelnykh vidov prestuplenii: ucheb. posobie [Criminalistic methodology of investigation of certain types of crimes: textbook] (KubGAU, Krasnodar, 2016)

16. A.Yu. Panov, Probl. Econ. and Legal Pract. 4 (2017) 